\title{
PENGARUH KESUKSESAN SISTEM DAPODIKDASMEN KOTA PALEMBANG MENGGUNAKAN MODEL DELONE DAN MCLEAN
}

\author{
Sri Rahayu ${ }^{1}$ \\ ${ }^{1}$ Jurusan Sistem Informasi, Fakultas Sains dan Teknologi, \\ Universitas Islam Negeri Raden Fatah Palembang \\ Email : srirahayu@radenfatah.ac.id
}

\begin{abstract}
ABSTRAK
Kesuksesan penerapan sistem informasi dalam suatu bidang pendidikan sangat penting diperhatikan. Pengaruh kesuksesan sistem dapodikdasmen Kota Palembang menggunakan model delone dan mclean belum dilakukan. Model yang digunakan untuk menganalisis kesuksesan sistem informasi adalah Model Delone dan Mclean. Penelitian ini berupa studi kasus dengan metode penelitian deskritif kuantitatif. Instrument penelitian berupa kuesioner yang berisi pernyataan dengan menggunakan likert sebagai alat ukur yang digunakan sehingga menghasilkan tingkat kesuksesan sistem informasi. Penelitian ini menggunakan 6 variabel Model Delone dan Mclean. Data dalam penelitian ini dikumpulkan dengan menggunakan kuesioner yang diberikan kepada responden. Hasil analisis didapatkan dari jawaban operator sekolah SMA dan SMK di kota palembang.
\end{abstract}

Kata Kunci: Kesuksesan, Delone dan McLean, likert

\begin{abstract}
The success of the application of information systems in an education field is very important to note. The effect of the success of the dapodikdasmen system in Palembang city using the delone dan mclean. The model used to analyze the success of information systems is the Delone and Mclean Model. This research is a case study with quantitative descriptive research methods. The research instrument was in the form of a questionnaire containing statements using Likert as a measurement tool used so as to produce an information system success rate. This study uses 6 Delone and Mclean Model variables. Data in this study were collected using a questionnaire given to respondents. The results of the analysis obtained from the answers of high school and high school operators in the city Palembang.
\end{abstract}

Keywords: Success, Delone and McLean, Likert

\section{PENDAHULUAN}

Penggunaan teknologi komputer sebagai alat teknologi informasi dalam dunia pendidikan memberikan nilai tambah proses pelaporan data, dalam dunia pendidikan keberadaan teknologi informasi juga sangat berguna bagi pihak manajemen (admaja, 2014). Untuk mewujudkan program pendidikan nasional yang tepat sasaran dan berkesinambungan dibutuhkan perencanaan tata kelola pendidikan. Berdasarkan instruksi menteri pendidikan nasional, Kementerian pendidikan dan kebudayaan (Kemdikbud) menggunakan sistem informasi data pokok pendidikan dasar dan menengah (Dapodikdasmen) untuk memperoleh data yang valid dan terbaru dari masing-masing sekolah pada jenjang pendidikan dasar.

Dapodikdasmen dikembangkan oleh Direktorat Jenderal Pendidikan Dasar dan Menengah sesuai dengan Instruksi Menteri No.2 Tahun 2011 tentang Kegiatan Pengelolaan Data Pendidikan dikembangkan dengan semangat satu nusa, satu bangsa, satu bahasa, satu data. Aplikasi ini berfungsi untuk menjaring data pokok pendidikan (Satuan Pendidikan, Peserta Didik serta pendidik dan tenaga kependidikan) yang akan dimanfaatkan dalam berbagai kebijakan pendidikan yaitu BOS, Bansos, Tunjangan, UN dan lain-lain. 
Beberapa model yang digunakan untuk menganalisis kesuksesan penerapan sistem informasi diantaranya model delone dan mclean, Technology Acceptance Model (TAM), Unified Theory Of Acceptance and Use of Technology (UTAUT). Salah satu model yang popular berfokus pada kesuksesan implemenasi di tingkat organisasi adalah model yang dikembangkan oleh delone dan mclean(1992) yang dikenal dengan model kesuksesan sistem informasi. Model ini memiliki ketergantungan dari enam variabel pengukuran kesuksesan sistem informasi, yakni : kualitas sistem, kualitas informasi, pemakaian, kepuasan pemakai, dampak individu dan dampak organisasional (Antong \& Usman. 2017). Pada tahun 2003 mclean dan delone kembali mengembangkan teorinya tentang kesuksesan sistem informasi dengan menambahkan kualitas pelayanan dan menggabungkan dampak individu dan dampak organisasional menjadi manfaat-manfaat bersih (Megawati \& Maflukhah, Nur'anini, 2017). Model yang dikembangkan oleh delone dan mclean ini cepat mendapat tanggapan, karena model mereka merupakan model yang sederhana tetapi dianggap cukup valid (Jumardi dkk, 2015).

Berdasarkan penjelasan yang diuraikan, penelitian ini akan berfokus pada kesuksesan penerapan sistem Dapodikdasmen di Provinsi Sumatera Selatan studi kasus SMA 118 dan SMK 79 di ada Kota Palembang, yang kemudian respondennya adalah 1 operator sekolah masing-masing. Penelitian ini untuk dijadikan bahan masukan bagi manajemen lembaga atau organisasi dalam memahami faktor-faktor penentu kesuksesan sistem dapodikdasmen sehingga kedepannya lembaga dapat meningkatkan kinerja dari sistem dapodikdasmen.

\section{METODE PENELITIAN}

Metode Penelitian merupakan cara ilmiah untuk mendapatkan data dengan tujuan dan kegunaan tertentu. Berdasarkan hal tersebut terdapat empat kata kunci yang perlu diperhatikan yaitu cara ilmiah, data, tujuan dan kegunaan. Cara ilmiah berarti didasarkan keilmuan. Rasional berarti kegiatan penelitian dilakukan dengan masuk akal. Empiris berarti cara-cara yang dilakukan dapat diamati oleh indera manusia. Sistematis artinya proses yang digunakan dalam penelitian itu menggunakan langkahlangkah tertentu yang bersifat logis.

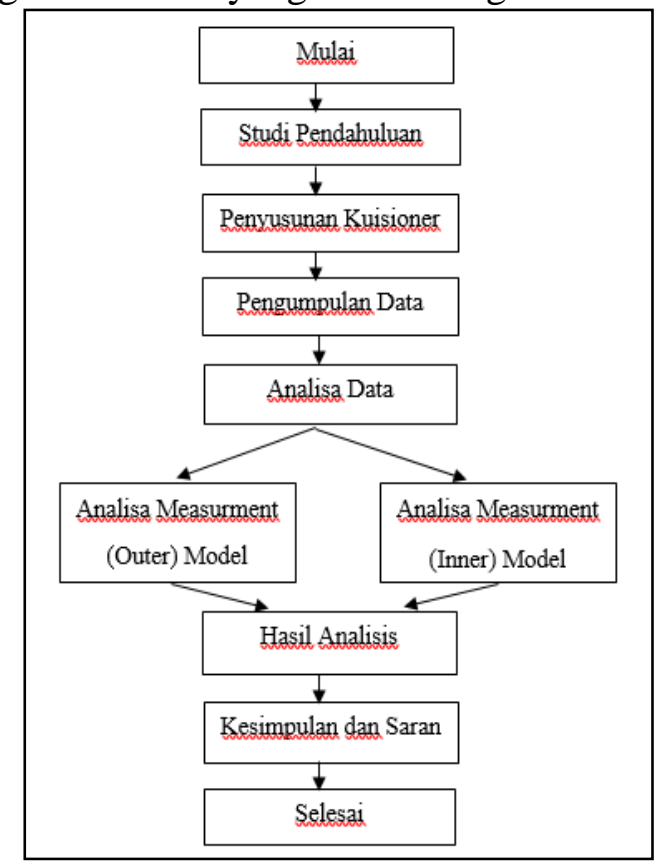

Gambar 1 Tahapan Penelitian

\subsection{Dapodikdasmen}

Dapodikdasmen dikembangkan oleh Direktorat Jenderal Pendidikan Dasar dan Menengah sesuai dengan Instruksi Menteri No.2 Tahun 2011 tentang Kegiatan Pengelolaan Data Pendidikan dikembangkan dengan semangat satu nusa, satu bangsa, satu bahasa, satu data. Aplikasi ini berfungsi untuk menjaring data pokok pendidikan (Satuan Pendidikan , Peserta Didik serta pendidik dan tenaga kependidikan) yang akan dimanfaatkan dalam berbagai kebijakan 
pendidikan yaitu BOS, Bansos,

\subsection{Kontekstualisasi Teori Dalam Riset}

Metode penelitian dalam penelitian ini adalah pendekatan kuantitatif dengan teknik pengumpulan data kuesioner. Metode kuantitatif disebut juga dengan metode positivistik karena berlandaskan pada filsafat positivisme (Darmawan, 2013). Metode ini sebagai metode ilmiah/scientific karena telah memenuhi kaidah-kaidah ilmiah yaitu konkrit/empiris, objektif, terukur, rasional, dan sistematis. Untuk mendapatkan hasil penelitian dilakukan metode kuisioner yang user nya adalah pengguna Dapodikdasmen yaitu operator sekolah. Untuk populasi pengguna Dapodikdasmen adalah operator sekolah 1 operator sekolah masing-masing sekolah. Operator sekolah SMA 118 operator dan SMK 79 operator. Maka pengguna dapodikdasmen di Kota Palembang adalah 197 operator. Dari populasi 197 diambil sampel 132 berdasarkan tabel krijcie.

Tabel 1. Tabel Krijcie

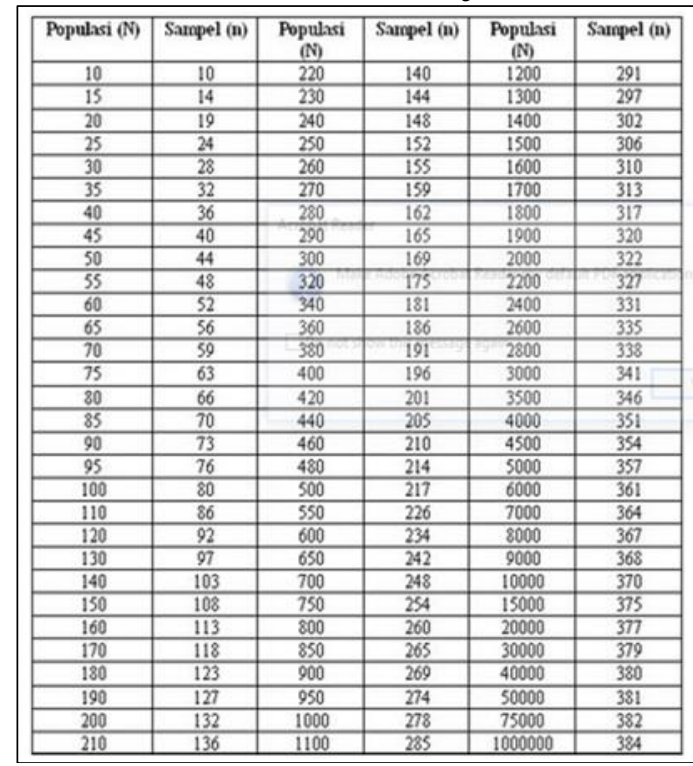

\subsection{Model Delone Dan Mclean}

Model Delone dan McLean adalah sebuah model yang digunakan untuk mengukur kesuksesan dari sistem
Tunjangan, UN dan lain-lain.

informasi, model ini dikenal sebagai model yang sederhana tetapi dianggap cukup valid oleh para peneliti. Model Delone dan McLean (1992) tercipta oleh para peneliti pada sekitar tahun 1970-an dan 1980-an.

Menurut Delone dan McLean kesuksesan sistem informasi terdiri dari 6 variabel yaitu :

1. System Quality yang digunakan untuk mengukur kualitas sistem teknologi informasinya sendiri.

2. Information Quality yang digunakan untuk mengukur kualitas keluaran dari sistem informasi

3. Use adalah penggunaan keluaran suatu sistem oleh penerima/pemakai

4. User Satisfaction adalah respon pemakai terhadap penggunaan keluaran sistem informasi

5. Individual Impact merupakan efek dari informasi terhadap perilaku pemakai

6. Organizational Impact merupakan pengaruh dari informasi terhadap kinerja organisasi

Secara singkat dapat dijelaskan bahwa hubungan antara kualitas sistem (system quality) dan kualitas informasi (information quality) secara independen dan bersama-sama mempengaruhi baik elemen penggunaan (use) dan kepuasan pemakai (user satisfaction). Besarnya elemen penggunaan (use) dapat mempengaruhi besarnya nilai kepuasan pemakai (user satisfaction) secara positif dan negatif. Penggunaan (use) dan kepuasan pemakai (user satisfaction) mempengaruhi dampak individual (individual impact) dan selanjutnya mempengaruhi dampak organisasional (organizational impact) (Jogiyanto, 2007:5)

Pada tahun 2003, Delone dan McLean kembali mengembangkan dan memperbaiki model kesuksesan sistem informasi yang sebelumnya telah mereka 
publikasikan pada tahun 1992.

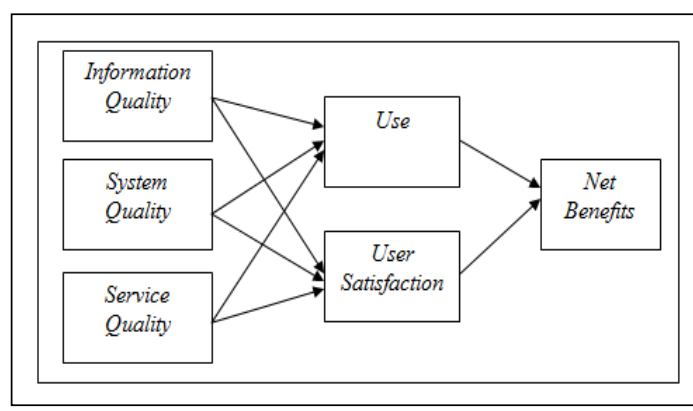

Gambar 2. Model Kesuksesan Sistem Informasi

\subsection{Pengujian}

Pada umumnya, regresi linear berganda terdiri atas dua atau lebih variabel. Satu variabel yang berupa variabel terikat/tergantung diberi simbol $\mathrm{Y}$ dan dua variabel kedua yang berupa variabel bebas diberi symbol X. Regresi linear berganda digunakan hanya untuk satu variabel tak bebas dan dua atau lebih variabel bebas (Aliyah, \& Tan, 2015). Persamaan yang dipergunakan untuk memprediksi nilai variabel $\mathrm{Y}$ disebut dengan persamaan regresi. Bentuk umum dari persamaan regresi dinyatakan dengan persamaan matematika yaitu :

$$
\mathrm{Y}=\mathrm{a}+\mathrm{b} \cdot \mathrm{X} 1+\mathrm{b} \cdot \mathrm{X} 2+\mathrm{b} \cdot \mathrm{X} 3
$$

Dimana :

$\mathrm{Y}=$ nilai prediksi dari variabel $\mathrm{Y}$ berdasarkan nilai variabel $X$

$\mathrm{a}=$ titik potong $\mathrm{Y}$, merupakan nilai bagi $\mathrm{Y}$ ketika $\mathrm{X}=0$

$\mathrm{b}=$ kemiringan atau slope atau perubahan rata-rata dalam $\mathrm{Y}$ untuk setiap perubahan dari satu unit $\mathrm{X}$, baik berupa peningkatan maupun penurunan

$X=$ nilai variabel $X$ yang dipilih

\subsection{Hipotesis}

Hipotesis merupakan jawaban sementara terhadap rumusan masalah penelitian, di mana rumusan masalah penelitian telah dinyatakan dalam bentuk kalimat pertanyaan. Dikatakan sementara, karena jawaban yang diberikan baru didasarkan pada fakta-fakta empiris yang diperoleh melalui pengumpulan data. Berdasarkan landasan teori dan paradigma penelitian maka disusun hipotesis sebagai berikut:

1. $H_{0}$ : Kualitas sistem (X1) berpengaruh signifikan terhadap pemakaian sistem dapodikdasmen (Y1).

$H_{a}$ : Kualitas sistem (X1) tidak berpengaruh signifikan terhadap pemakaian sistem dapodikdasmen (Y1).

2. 2. $H_{0}$ : Kualitas informasi (X2) berpengaruh signifikan terhadap pemakaian sistem dapodikdasmen (Y1). $H_{a}$ : Kualitas informasi (X2) tidak berpengaruh signifikan terhadap pemakaian sistem dapodikdasmen (Y1).

3. $H_{0}$ : Kualitas layanan (X3) berpengaruh signifikan terhadap pemakaian sistem dapodikdasmen (Y1).

$H_{a}$ : Kualitas layanan (X3) tidak berpengaruh signifikan terhadap pemakaian sistem dapodikdasmen (Y1).

4. $H_{0}$ : Kualitas sistem (X1) berpengaruh signifikan terhadap kepuasan pemakai sistem dapodikdasmen (Y2).

$H_{a}$ : Kualitas sistem (X1) tidak berpengaruh signifikan terhadap kepuasan pemakai sistem dapodikdasmen (Y2).

5. $H_{0}$ :Kualitas informasi (X2) berpengaruh signifikan terhadap kepuasan pemakai sistem dapodikdasmen (Y2).

$H_{a}$ : Kualitas informasi (X2) tidak berpengaruh signifikan terhadap kepuasan pemakai sistem dapodikdasmen (Y2).

6. $H_{0}$ : Kualitas layanan (X3) berpengaruh signifikan terhadap kepuasan pemakai sistem dapodikdasmen (Y2).

$H_{a}$ : Kualitas layanan (X3) tidak berpengaruh signifikan terhadap kepuasan pemakai sistem dapodikdasmen (Y2).

7. $H_{0}$ : Pemakaian (Y1) berpengaruh signifikan terhadap Kepuasan pemakai sistem dapodikdasmen (Y2)

$H_{a}$ : Pemakaian (Y1) tidak berpengaruh signifikan terhadap Kepuasan pemakai sistem dapodikdasmen (Y2) 
8. $H_{0}$ : Pemakaian (Y1) berpengaruh signifikan terhadap Net Benefit (Z).

$H_{a}$ : Pemakaian (Y1) tidak berpengaruh signifikan terhadap Net Benefit (Z).

9. $H_{0}:$ Kepuasan pemakai (Y2) berpengaruh signifikan terhadap Net Benefit (Z).

$H_{a}$ : Kepuasan pemakai(Y2) tidak berpengaruh signifikan terhadap Net Benefit (Z).

\section{HASIL DAN PEMBAHASAN}

\subsection{Uji Validitas dan Uji Reliabilitas}

Dalam penelitian ini menggunakan taraf signifikansi 5\%. Sampel yang digunakan dalam uji validasi adalah 20 sampel. Dimana,diberikan ke operator sekolah SMA dan SMK di Kota Palembang. Tingkat signifikan :

$$
\begin{aligned}
\text { Df } & =\mathrm{N}-2 \\
& =132-2 \\
& =130
\end{aligned}
$$

\begin{tabular}{|c|c|c|c|c|}
\hline Variabel & Pernyataan & $\begin{array}{c}\mathrm{r} \\
\text { hitung }\end{array}$ & $\begin{array}{c}\mathrm{r} \\
\text { tabel }\end{array}$ & Hasil \\
\hline \multirow{5}{*}{$\begin{array}{l}\text { Kualitas } \\
\text { Informasi }\end{array}$} & 1 & 0,654 & 0,143 & Valid \\
\hline & 2 & 0,680 & 0,143 & Valid \\
\hline & 3 & 0,855 & 0,143 & Valid \\
\hline & 4 & 0,855 & 0,143 & Valid \\
\hline & 5 & 0,581 & 0,143 & Valid \\
\hline \multirow{6}{*}{$\begin{array}{l}\text { Kualitas } \\
\text { Sistem }\end{array}$} & 1 & 0,737 & 0,143 & Valid \\
\hline & 2 & 0,708 & 0,143 & Valid \\
\hline & 3 & 0,603 & 0,143 & Valid \\
\hline & 4 & 0,717 & 0,143 & Valid \\
\hline & 5 & 0,708 & 0,143 & Valid \\
\hline & 6 & 0,765 & 0,143 & Valid \\
\hline \multirow{3}{*}{$\begin{array}{l}\text { Kualitas } \\
\text { Pelayanan }\end{array}$} & 1 & 0,871 & 0,143 & Valid \\
\hline & 2 & 0,803 & 0,143 & Valid \\
\hline & 3 & 0,820 & 0,143 & Valid \\
\hline \multirow[t]{2}{*}{ Pemakaian } & 1 & 0,896 & 0,143 & Valid \\
\hline & 2 & 0,855 & 0,143 & Valid \\
\hline \multirow{3}{*}{$\begin{array}{l}\text { Kepuasan } \\
\text { Pemakai }\end{array}$} & 1 & 0,797 & 0,143 & Valid \\
\hline & 2 & 0,798 & 0,143 & Valid \\
\hline & 3 & 0,672 & 0,143 & Valid \\
\hline $\begin{array}{l}\text { Net } \\
\text { Benefit }\end{array}$ & 1 & 1,000 & 0,143 & Valid \\
\hline
\end{tabular}

Taraf signifikan $\mathrm{r}$ tabelnya adalah 0,143 .

Tabel 2. Hasil Analisis Uji Validitas

Ringkasan hasil uji reliabilitas instrumen penelitian per-variabel dapat dilihat pada Tabel 3.
Tabel 3. Uji Reliabilitas Variabel

\begin{tabular}{|c|c|c|c|}
\hline Variabel & $\begin{array}{c}\text { Jumlah } \\
\text { Item }\end{array}$ & $\begin{array}{c}\text { Crobach } \\
\text { 's Alpa }\end{array}$ & Keterangan \\
\hline $\begin{array}{c}\text { Kualitas } \\
\text { Sistem }\end{array}$ & 6 & 0,796 & $\begin{array}{c}\text { Reliabilitas } \\
\text { Tinggi }\end{array}$ \\
\hline $\begin{array}{c}\text { Kualitas } \\
\text { Informas } \\
\mathrm{i}\end{array}$ & 5 & 0,782 & $\begin{array}{c}\text { Reliabilitas } \\
\text { Tinggi }\end{array}$ \\
\hline $\begin{array}{c}\text { Kualitas } \\
\text { Pelayana } \\
\mathrm{n}\end{array}$ & 3 & 0,778 & $\begin{array}{c}\text { Reliabilitas } \\
\text { Tinggi }\end{array}$ \\
\hline $\begin{array}{c}\text { Pemakai } \\
\text { an }\end{array}$ & 2 & 0,692 & $\begin{array}{c}\text { Reliabilitas } \\
\text { Moderat }\end{array}$ \\
\hline $\begin{array}{c}\text { Kepuasa } \\
\mathrm{n}\end{array}$ & 3 & 0,682 & $\begin{array}{c}\text { Reliabilitas } \\
\text { Moderat }\end{array}$ \\
\hline $\begin{array}{c}\text { Pemakai } \\
\text { Banfaat }\end{array}$ & 1 & 1,000 & $\begin{array}{c}\text { Reliabilitas } \\
\text { Sempurna }\end{array}$ \\
\hline
\end{tabular}

Dapat diketahui bahwa instrumen penelitian untuk semua subdimensi dan variabel bersifat valid. Sedangkan hasil uji reliabilitas menunjukkan bahwa untuk semua subdimensi dan variabel bersifat reliable. Sehingga data penelitian valid dan layak digunakan untuk pengujian hipotesis penelitian selanjutnya.

\subsection{Uji Asumsi Klasik}

\subsubsection{Uji Normalitas}

Uji Normalitas pada model regresi digunakan untuk menguji apakah nilai residual yang dihasilkan dari regresi terdistribusi secara normal atau tidak. Pada penelitian ini metode yang digunakan untuk menguji normalitas data adalah dengan menggunakan Grafik P-P Plot. Hasil dari pengujian uji Normalitas dapat dilihat pada Gambar 3.

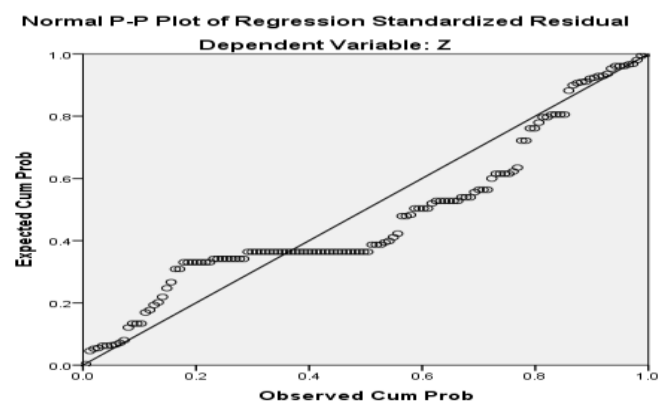

Gambar 3. Uji Normalitas 


\subsubsection{Uji Multikolinearlitas}

Uji Muktikolinearlitas pada penelitian ini menggunakan VIF dan Tolerance.

Tabel 4. Uji Muktikolinearlitas SPSS

\begin{tabular}{|c|r|r|}
\hline \multirow{2}{*}{ Model } & \multicolumn{2}{|c|}{$\begin{array}{c}\text { Collinearity } \\
\text { Statistics }\end{array}$} \\
\cline { 2 - 3 } & Tolerance & VIF \\
\hline X1 & .380 & 2.634 \\
X2 & .389 & 2.571 \\
X3 & .607 & 1.646 \\
Y1 & .516 & 1.937 \\
Y2 & .567 & 1.763 \\
\hline
\end{tabular}

Dari Tabel 4 dapat kita ambil keputusan apakah variable dari penelitian ini. Maka untuk mengambil keputusan itu berdasarkan dengan nilai VIF dan Tolerance, jika nilai VIF kurang dari 10 dan nilai Tolerance lebih kecil 0,1, maka dinyatakan tidak terjadi multikolinearlitas. Maka dapat diperhatikan pada Tabel 5.

Tabel 5. Hasil Keputusan Uji multikolinearlitas

\begin{tabular}{|c|c|c|c|c|}
\hline$N_{0}$ & Tariabel & Nilai VIF & Nilai Tolerance & Keterangan \\
\hline 1 & Kualitas Sistem & $2.634<10$ & $0.380>0,1$ & $\begin{array}{l}\text { Tidak Terjadi } \\
\text { Multilkolinearitas }\end{array}$ \\
\hline 2 & Kualitas Informasi & $2.571<10$ & $0.389>0,1$ & $\begin{array}{lr}\text { Tidak } & \text { Tejadi } \\
\text { Multilkolinearitas }\end{array}$ \\
\hline 3 & Kualitas Pelayanan & $1.646<10$ & $0.607>0,1$ & $\begin{array}{l}\text { Tidak Terjadi } \\
\text { Multilkolinesritss }\end{array}$ \\
\hline 4 & Penalkain & $1.937<10$ & $0.516>0,1$ & $\begin{array}{l}\text { Tidak Terjadi } \\
\text { Multikolinesritas }\end{array}$ \\
\hline 5 & Kepuasan Pemaksian & $1.763<10$ & $0.567>0,1$ & $\begin{array}{lr}\text { Tidak Terjadi } \\
\text { Multilkolinearitas }\end{array}$ \\
\hline
\end{tabular}

\subsubsection{Uji Heterokedastisitas}

Penelitian ini untuk melakukan pengujian dengan menggunakan teknik Scatterplots Regresi. Metode ini dilakukan dengan cara melihat grafik Scatterplots antara SRESID dan ZPRED dimana sumbu $\mathrm{Y}$ adalah $\mathrm{Y}$ yang telah diprediksi dan sumbu $X$ adalah residual (Y prediksi - Y sesungguhnya). Jika ada pola tertentu, seperti titik-titik yang ada membentuk suatu pola tertentu yang teratur (bergelombang, melebar kemudian menyempit),

maka terjadi heterokedastisitas, sedangkan jika tidak ada pola yang jelas, seperti titik-titik menyebar diatas dan dibawah angka 0 pada sumbu Y, maka tidak terjadi heterokedastisitas

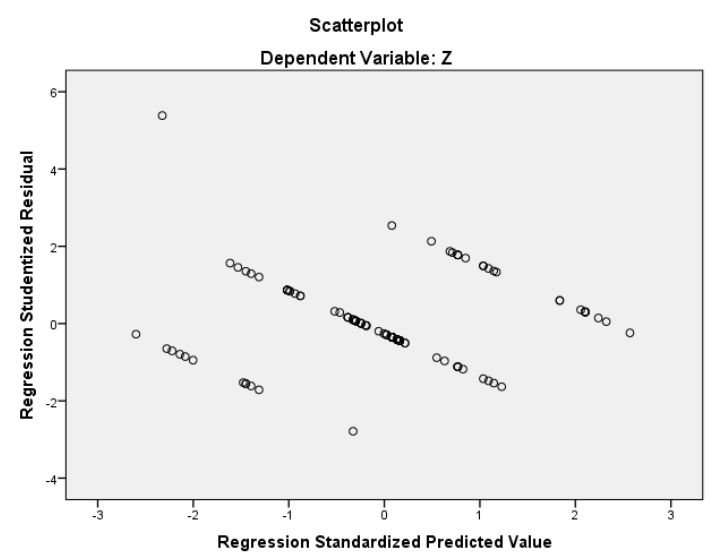

Gambar 4. Hasil Uji Heterodekastisitas

Dari Gambar 4. dapat kita lihat tidak ada pola yang jelas dan titik-titiknya menyebar diatas dan dibawah angka 0 pada sumbu Y, maka dapat dikatakan tidak terjadi heterokedastisitas.

\subsubsection{Uji Regresi Linear Berganda}

3.2.4.1 Uji Regresi Linear Berganda Model 1 terhadap Pemakaian (Y1)

Dalam regresi linear berganda terdapat asumsi klasik yang harus terpenuhi, yaitu residual terdistribusi normal, tidak adanya multikolinearlitas dan tidak adanya heterokedastisitas pada model regresi.

Tabel 6. Hasil Regresi Model 1

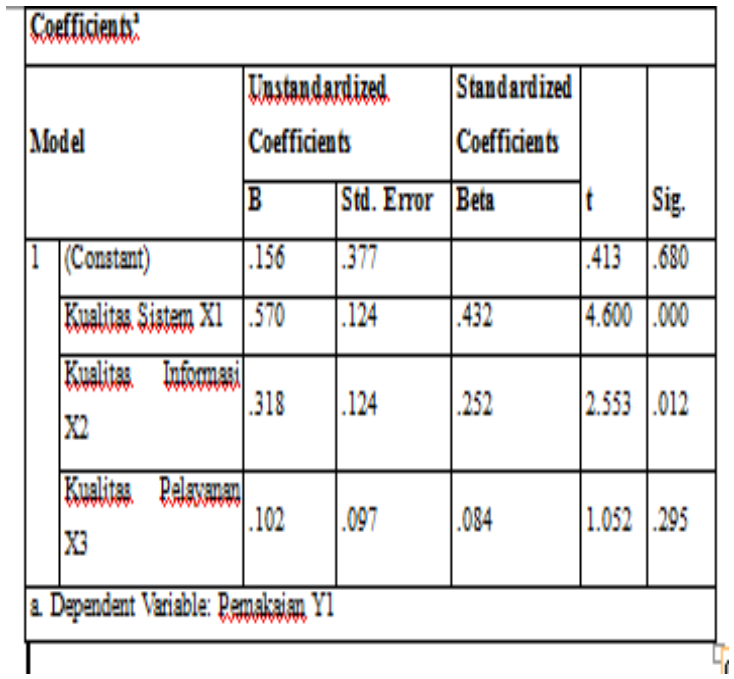


persamaan Model 1 regresi berganda

sebagai berikut :

$\mathrm{Y}=\mathrm{a}+\mathrm{b}_{1} \mathrm{X}_{1}+\mathrm{b}_{2} \mathrm{X}_{2}+\mathrm{b}_{3} \mathrm{X}_{3}$

$Y=0,156+0,570 X_{1}+0,318 X_{2}+0,102 X_{3}$

Dengan hasil persamaan pada Tabel 6. tersebut memberikan perhatian sebagai berikut :

1. Jika Kualitas Sistem $\left(\mathrm{X}_{1}\right)$, Kualitas Informasi $\left(\mathrm{X}_{2}\right)$, Kualitas Pelayanan $\left(\mathrm{X}_{3}\right)$, mendekati atau sama dengan 0 , maka Pemakaian $\left(\mathrm{Y}_{1}\right)=0.156$. dengan interpretasi bahwa jika $X_{1}, X_{2}$, dan $X_{3}$ rendah, maka rata-rata penggunaan tetap 0,156 .

2. Jika Kualitas Sistem $\left(\mathrm{X}_{1}\right)$ terhadap Pemakaian $\left(\mathrm{Y}_{1}\right)$ adalah sebesar 0,507. Nilai ini menunjukan lemah positif, maksud lemah positif disini adalah tejadi hubungan yang searah antara $X_{1}$

3. dan $Y_{1}$. Dengan interpretasi bahwa setiap nilai Kualitas Sistem $\left(\mathrm{X}_{1}\right)$ naik, nilai Pemakaian $\left(Y_{1}\right)$ tidak naik secara signifikan.

4. Jika Kualitas Informasi $\left(X_{2}\right)$ terhadap Pemakaian $\left(\mathrm{Y}_{1}\right)$ adalah sebesar 0,318. Nilai ini menunjukan lemah positif, maksud lemah positif disini adalah tejadi hubungan yang searah antara $\mathrm{X}_{2}$ dan $Y_{1}$. Dengan interpretasi bahwa setiap nilai Kualitas Informasi $\left(\mathrm{X}_{2}\right)$ naik, nilai Pemakaian $\left(\mathrm{Y}_{1}\right)$ tidak naik secara signifikan.

5. Jika Kualitas Pelayanan $\left(X_{3}\right)$ terhadap Pemakaian $\left(\mathrm{Y}_{1}\right)$ adalah sebesar 0,102. Nilai ini menunjukan lemah positif, maksud lemah positif disini adalah tejadi hubungan yang searah antara $X_{3}$ dan $Y_{1}$. Dengan interpretasi bahwa setiap nilai Kualitas Pelayanan $\left(\mathrm{X}_{3}\right)$ naik, nilai Pemakaian $\left(\mathrm{Y}_{1}\right)$ tidak naik secara signifikan.

\subsubsection{Uji Regresi Linear Berganda Model 2 terhadap Net Benefits $(\mathrm{Z})$}

Dalam regresi linear berganda terdapat asumsi klasik yang harus terpenuhi, yaitu residual terdistribusi normal, tidak adanya multikolinearlitas dan tidak adanya heterokedastisitas pada model regresi.

Tabel 7. Hasil Regresi Model 2 Menggunakan SPSS

\begin{tabular}{|c|c|c|c|c|c|c|}
\hline \multicolumn{7}{|c|}{ Coefficients $^{\mathrm{a}}$} \\
\hline \multirow{2}{*}{\multicolumn{2}{|c|}{ Model }} & \multicolumn{2}{|c|}{\begin{tabular}{|l} 
Unstandardized \\
Coefficients
\end{tabular}} & \multirow{2}{*}{\begin{tabular}{|l|}
$\begin{array}{l}\text { Standardized } \\
\text { Coefficients }\end{array}$ \\
Beta
\end{tabular}} & \multirow[t]{2}{*}{$t$} & \multirow[t]{2}{*}{ Sig. } \\
\hline & & B & Std. Error & & & \\
\hline \multirow[t]{5}{*}{1} & (Constant) & 1.632 & .399 & & 4.093 & .000 \\
\hline & Kualitas Sistem X1 & .082 & .141 & .071 & .582 & .561 \\
\hline & $\begin{array}{ll}\text { Kualitas } & \text { Informasi } \\
\mathrm{X} 2 & \\
\end{array}$ & .331 & .135 & .300 & 2.456 & .015 \\
\hline & $\begin{array}{ll}\text { Kualitas } & \text { Pelayanan } \\
\text { X3 } & \\
\end{array}$ & .255 & .102 & 240 & 2.496 & .014 \\
\hline & Pemakaian Y1 & -.051 & .093 & -.058 & -.543 & .588 \\
\hline
\end{tabular}

Dari Tabel 7 didapatkan persamaan Model 2 regresi berganda sebagai berikut :

$\mathrm{Y}=\mathrm{a}+\mathrm{b}_{1} \mathrm{X}_{1}+\mathrm{b}_{2} \mathrm{X}_{2}+\mathrm{b}_{3} \mathrm{X}_{3}+\mathrm{b}_{4} \mathrm{X}_{4}$

$Y=1,632+0,082 X_{1}+0,331 X_{2}+0,255$

$\mathrm{X}_{3}+\left(-0,051 \mathrm{X}_{4}\right)$

Dengan hasil persamaan pada Tabel tersebut memberikan perhatian sebagai berikut :

1. Jika Kualitas Sistem $\left(\mathrm{X}_{1}\right)$, Kualitas Informasi $\left(\mathrm{X}_{2}\right)$, Kualitas Pelayanan $\left(\mathrm{X}_{3}\right)$, dan Pemakaian $\left(\mathrm{Y}_{1}\right)$ mendekati atau sama dengan 0 , maka Net Benefits $(Z)=1.632$. dengan interpretasi bahwa jika $\mathrm{X}_{1}, \mathrm{X}_{2}, \mathrm{X}_{3}$ dan $\mathrm{X}_{4}$ rendah, maka rata-rata penggunaan tetap 1.632.

2. Jika Kualitas Sistem $\left(\mathrm{X}_{1}\right)$ terhadap Net Benefits (Z) adalah sebesar 0,082. Nilai ini menunjukan lemah positif, maksud lemah positif disini adalah tejadi hubungan yang searah antara $\mathrm{X}_{1}$ dan Z. Dengan interpretasi bahwa setiap nilai Kualitas Sistem $\left(\mathrm{X}_{1}\right)$ naik, nilai Net Benefits $(\mathrm{Z})$ tidak naik secara signifikan.

3. Jika Kualitas Informasi $\left(\mathrm{X}_{2}\right)$ terhadap Net Benefits (Z) adalah sebesar 0,331. Nilai ini menunjukan lemah positif, maksud lemah positif disini adalah tejadi hubungan yang searah antara $\mathrm{X}_{2}$ dan Z. Dengan interpretasi bahwa setiap nilai Kualitas Informasi $\left(\mathrm{X}_{2}\right)$ 
naik, nilai Net Benefits (Z) tidak naik secara signifikan.

4. Jika Kualitas Pelayanan $\left(\mathrm{X}_{3}\right)$ terhadap Net Benefits (Z) adalah sebesar 0,255. Nilai ini menunjukan lemah positif, maksud lemah positif disini adalah tejadi hubungan yang searah antara $X_{3}$ dan Z. Dengan interpretasi bahwa setiap nilai Kualitas Pelayanan $\left(\mathrm{X}_{3}\right)$ naik, nilai Net Benefits (Z) tidak naik secara signifikan.

5. Jika Pemakaian $\left(\mathrm{Y}_{1}\right)$ terhadap Net Benefits (Z) adalah sebesar $-0,051$. Nilai ini menunjukan lemah positif, maksud lemah positif disini adalah tejadi hubungan yang searah antara $\mathrm{Y}_{1}$ dan Z. Dengan interpretasi bahwa setiap nilai Pemakaian $\left(\mathrm{Y}_{1}\right)$ naik, nilai Net Benefits (Z) tidak naik secara signifikan.

\subsubsection{Uji Regresi Linear Berganda} Model 3 terhadap Kepuasan Pemakai

Dalam regresi linear berganda terdapat asumsi klasik yang harus terpenuhi, yaitu residual terdistribusi normal, tidak adanya multikolinearlitas dan tidak adanya heterokedastisitas pada model regresi.

Tabel 8. Hasil Regresi Model 3 Menggunakan SPSS

\begin{tabular}{|c|c|c|c|c|c|c|}
\hline \multicolumn{7}{|c|}{ Coefficients $^{\mathrm{a}}$} \\
\hline \multirow{2}{*}{\multicolumn{2}{|c|}{ Model }} & \multicolumn{2}{|c|}{$\begin{array}{l}\text { Unstandardized } \\
\text { Coefficients }\end{array}$} & \multirow{2}{*}{\begin{tabular}{|l|}
$\begin{array}{l}\text { Standardized } \\
\text { Coefficients }\end{array}$ \\
Beta
\end{tabular}} & \multirow[t]{2}{*}{$t$} & \multirow[t]{2}{*}{ Sig. } \\
\hline & & B & Std. Error & & & \\
\hline \multirow[t]{4}{*}{1} & (Constant) & .947 & .312 & & 3.039 & .003 \\
\hline & Kualitas Sistem X1 & .322 & .102 & .310 & 3.152 & .002 \\
\hline & $\begin{array}{ll}\text { Kualitas } & \text { Informasi } \\
\mathrm{X} 2 & \\
\end{array}$ & .212 & .103 & .214 & 2.066 & .041 \\
\hline & \begin{tabular}{ll|} 
Kualitas & Pelayanan \\
X3 & \\
\end{tabular} & .224 & .080 & .234 & 2.806 & .006 \\
\hline
\end{tabular}

Data dari Tabel 8. didapatkan persamaan Model 3 regresi berganda sebagai berikut :

$\mathrm{Y}=\mathrm{a}+\mathrm{b}_{1} \mathrm{X}_{1}+\mathrm{b}_{2} \mathrm{X}_{2}+\mathrm{b}_{3} \mathrm{X}_{3}$

$Y=0,947+0,322 X_{1}+0,212 X_{2}+0,224 X_{3}$
Dengan hasil persamaan pada Tabel tersebut memberikan perhatian sebagai berikut :

1. Jika Kualitas Sistem $\left(\mathrm{X}_{1}\right)$, Kualitas Informasi $\left(\mathrm{X}_{2}\right)$, Kualitas Pelayanan $\left(\mathrm{X}_{3}\right)$, mendekati atau sama dengan 0 , maka Kepuasan Pemakaian $\left(\mathrm{Y}_{2}\right)=$ 0,947. dengan interpretasi bahwa jika $\mathrm{X}_{1}, \mathrm{X}_{2}$, dan $\mathrm{X}_{3}$ rendah, maka rata-rata penggunaan tetap 0,947 .

2. Jika Kualitas Sistem $\left(X_{1}\right)$ terhadap Kepuasan Pemakaian $\left(\mathrm{Y}_{2}\right)$ adalah sebesar 0,322. Nilai ini menunjukan lemah positif, maksud lemah positif disini adalah tejadi hubungan yang searah antara $X_{1}$ dan $Y_{2}$. Dengan interpretasi bahwa setiap nilai Kualitas Sistem $\left(\mathrm{X}_{1}\right)$ naik, nilai Kepuasan Pemakaian $\left(\mathrm{Y}_{2}\right)$ tidak naik secara signifikan.

3. Jika Kualitas Informasi $\left(\mathrm{X}_{2}\right)$ terhadap Kepuasan Pemakaian $\left(\mathrm{Y}_{2}\right)$ adalah sebesar 0,212. Nilai ini menunjukan lemah positif, maksud lemah positif disini adalah tejadi hubungan yang searah antara $\mathrm{X}_{2}$ dan $\mathrm{Y}_{2}$. Dengan interpretasi bahwa setiap nilai Kualitas Informasi $\left(\mathrm{X}_{2}\right)$ naik, nilai Kepuasan Pemakaian $\left(\mathrm{Y}_{2}\right)$ tidak naik secara signifikan.

4. Jika Kualitas Pelayanan $\left(\mathrm{X}_{3}\right)$ terhadap Kepuasan Pemakaian $\left(\mathrm{Y}_{2}\right)$ adalah sebesar 0,224. Nilai ini menunjukan lemah positif, maksud lemah positif disini adalah tejadi hubungan yang searah antara $\mathrm{X}_{3}$ dan $\mathrm{Y}_{2}$. Dengan interpretasi bahwa setiap nilai Kualitas Pelayanan $\left(\mathrm{X}_{3}\right)$ naik, nilai Kepuasan Pemakaian $\left(\mathrm{Y}_{2}\right)$ tidak naik secara signifikan.

3.2.4.4 Uji Regresi Linear Berganda Model 4 terhadap Net Benefits (Z)

Dalam regresi linear berganda terdapat asumsi klasik yang harus terpenuhi, yaitu residual terdistribusi normal, tidak adanya multikolinearlitas dan tidak adanya heterokedastisitas pada model regresi. 
Tabel 9. Hasil Regresi Model 4 Menggunakan SPSS

\begin{tabular}{|c|c|c|c|c|c|c|}
\hline \multicolumn{7}{|c|}{ Coefficients ${ }^{\mathrm{a}}$} \\
\hline \multirow{3}{*}{\multicolumn{2}{|c|}{ Model }} & \multirow{2}{*}{\multicolumn{2}{|c|}{$\begin{array}{l}\text { Unstandardized } \\
\text { Coefficients }\end{array}$}} & \multirow{3}{*}{\begin{tabular}{|l|}
$\begin{array}{l}\text { Standardized } \\
\text { Coefficients }\end{array}$ \\
Beta
\end{tabular}} & \multirow{3}{*}{$\mathbf{T}$} & \multirow{3}{*}{ Sig. } \\
\hline & & & & & & \\
\hline & & \multirow{2}{*}{\begin{tabular}{|l|} 
B \\
.839 \\
\end{tabular}} & \multirow{2}{*}{\begin{tabular}{|l|}
$\begin{array}{l}\text { Std. } \\
\text { Error }\end{array}$ \\
.314 \\
\end{tabular}} & & & \\
\hline 1 & (Constant) & & & & 2.673 & .009 \\
\hline & Kualitas Sistem X1 & -.214 & .103 & -.185 & -2.072 & .040 \\
\hline & Kualitas Informasi X2 & .139 & .102 & .126 & 1.365 & .175 \\
\hline & Kualitas Pelayanan X3 & .065 & .080 & .061 & .813 & .418 \\
\hline & $\begin{array}{ll}\text { Kepuasan } & \text { Pemakaian } \\
\text { Y2 } & \end{array}$ & .829 & .086 & .745 & 9.646 & .000 \\
\hline
\end{tabular}

Dari Tabel 9. didapatkan persamaan Model 4 regresi berganda sebagai berikut

$\mathrm{Y}=\mathrm{a}+\mathrm{b}_{1} \mathrm{X}_{1}+\mathrm{b}_{2} \mathrm{X}_{2}+\mathrm{b}_{3} \mathrm{X}_{3}+\mathrm{b}_{4} \mathrm{X}_{4}$ $\mathrm{Y}=0,839+(-0,214) \mathrm{X}_{1}+0,139 \mathrm{X}_{2}+0,065$ $\mathrm{X}_{3}+0,829 \mathrm{X}_{4}$

Dengan hasil persamaan pada Tabel tersebut memberikan perhatian sebagai berikut :

1. Jika Kualitas Sistem $\left(\mathrm{X}_{1}\right)$, Kualitas Informasi $\left(\mathrm{X}_{2}\right)$, Kualitas Pelayanan $\left(\mathrm{X}_{3}\right)$, dan Kepuasan Pemakaian $\left(\mathrm{Y}_{2}\right)$ mendekati atau sama dengan 0 , maka Net Benefits $(\mathrm{Z})=0,839$. dengan interpretasi bahwa jika $\mathrm{X}_{1}, \mathrm{X}_{2}, \mathrm{X}_{3}$ dan $\mathrm{X}_{4}$ rendah, maka rata-rata penggunaan tetap 0,839 .

2. Jika Kualitas Sistem $\left(\mathrm{X}_{1}\right)$ terhadap Net Benefits (Z) adalah sebesar - 0,214. Nilai ini menunjukan lemah positif, maksud lemah positif disini adalah tejadi hubungan yang searah antara $\mathrm{X}_{1}$ dan Z. Dengan interpretasi bahwa setiap nilai Kualitas Sistem $\left(\mathrm{X}_{1}\right)$ naik, nilai Net Benefits $(\mathrm{Z})$ tidak naik secara signifikan.

3. Jika Kualitas Informasi $\left(\mathrm{X}_{2}\right)$ terhadap Net Benefits (Z) adalah sebesar 0,139. Nilai ini menunjukan lemah positif, maksud lemah positif disini adalah tejadi hubungan yang searah antara $\mathrm{X}_{2}$ dan Z. Dengan interpretasi bahwa setiap nilai Kualitas Informasi $\left(\mathrm{X}_{2}\right)$ naik, nilai Net Benefits (Z) tidak naik secara signifikan.
4. Jika Kualitas Pelayanan $\left(\mathrm{X}_{3}\right)$ terhadap Net Benefits (Z) adalah sebesar 0,065. Nilai ini menunjukan lemah positif, maksud lemah positif disini adalah tejadi hubungan yang searah antara $\mathrm{X}_{3}$ dan Z. Dengan interpretasi bahwa setiap nilai Kualitas Pelayanan $\left(X_{3}\right)$ naik, nilai Net Benefits (Z) tidak naik secara signifikan.

5. Jika Kepuasan Pemakaian $\left(\mathrm{Y}_{2}\right)$ terhadap Net Benefits (Z) adalah sebesar 0,829. Nilai ini menunjukan lemah positif, maksud lemah positif disini adalah tejadi hubungan yang searah antara $\mathrm{Y}_{2}$ dan $\mathrm{Z}$. Dengan interpretasi bahwa setiap nilai Kepuasan Pemakaian $\left(\mathrm{Y}_{2}\right)$ naik, nilai Net Benefits (Z) tidak naik secara signifikan.

3.2.4.5 Uji Regresi Linear Berganda Model 5 terhadap Kepuasan Pemakaian $\left(\mathrm{Y}_{2}\right)$

Dalam regresi linear berganda terdapat asumsi klasik yang harus terpenuhi, yaitu residual terdistribusi normal, tidak adanya multikolinearlitas dan tidak adanya heterokedastisitas pada model regresi.

Tabel 10. Hasil Regresi Model 5 Menggunakan SPSS

\begin{tabular}{|c|c|c|c|c|c|c|}
\hline \multirow{2}{*}{\multicolumn{2}{|c|}{ Model }} & \multicolumn{2}{|c|}{$\begin{array}{l}\text { Unstandardized } \\
\text { Coefficients }\end{array}$} & \multirow{2}{*}{\begin{tabular}{|l}
$\begin{array}{l}\text { Standardized } \\
\text { Coefficients }\end{array}$ \\
Beta
\end{tabular}} & \multirow[t]{2}{*}{ T } & \multirow[t]{2}{*}{ Sig. } \\
\hline & & B & Std. Error & & & \\
\hline \multirow[t]{5}{*}{1} & (Constant) & .932 & .311 & & 2.998 & .003 \\
\hline & Kualitas Sistem X1 & .268 & .110 & .258 & 2.434 & .016 \\
\hline & $\begin{array}{ll}\text { Kualitas } & \text { Informasi } \\
\mathrm{X} 2 & \end{array}$ & .182 & .105 & .184 & 1.733 & .086 \\
\hline & \begin{tabular}{|ll} 
Kualitas & Pelayanan \\
X3 & \\
\end{tabular} & .214 & .080 & .224 & 2.680 & .008 \\
\hline & Pemakaian Y1 & .095 & $\mid .073$ & .121 & 1.310 & 193 \\
\hline
\end{tabular}

Data dari Tabel 10. didapatkan persamaan Model 5 regresi berganda sebagai berikut :

$\mathrm{Y}=\mathrm{a}+\mathrm{b}_{1} \mathrm{X}_{1}+\mathrm{b}_{2} \mathrm{X}_{2}+\mathrm{b}_{3} \mathrm{X}_{3}+\mathrm{b}_{4} \mathrm{X}_{4}$

$Y=0,932+0,268 X_{1}+0,182 X_{2}+0,214 X_{3}$ $+0,095 \mathrm{X}_{4}$

Dengan hasil persamaan pada tabel tersebut memberikan perhatian sebagai 
berikut :

1. Jika Kualitas Sistem $\left(\mathrm{X}_{1}\right)$, Kualitas Informasi $\left(\mathrm{X}_{2}\right)$, Kualitas Pelayanan $\left(\mathrm{X}_{3}\right)$, dan Pemakaian $\left(\mathrm{Y}_{1}\right)$ mendekati atau sama dengan 0, maka Kepuasan Pemakaian $\left(\mathrm{Y}_{2}\right)=0,932$. dengan interpretasi bahwa jika $\mathrm{X}_{1}, \mathrm{X}_{2}, \mathrm{X}_{3}$ dan $\mathrm{X}_{4}$ rendah, maka rata-rata penggunaan tetap 0,932 .

2. Jika Kualitas Sistem $\left(\mathrm{X}_{1}\right)$ terhadap Kepuasan Pemakaian $\left(\mathrm{Y}_{2}\right)$ adalah sebesar 0,268. Nilai ini menunjukan lemah positif, maksud lemah positif disini adalah tejadi hubungan yang searah antara $X_{1}$ dan $Y_{2}$. Dengan interpretasi bahwa setiap nilai Kualitas Sistem $\left(\mathrm{X}_{1}\right)$ naik, nilai Kepuasan Pemakaian $\left(\mathrm{Y}_{2}\right)$ tidak naik secara signifikan.

3. Jika Kualitas Informasi $\left(\mathrm{X}_{2}\right)$ terhadap Kepuasan Pemakaian $\left(\mathrm{Y}_{2}\right)$ adalah sebesar 0,182. Nilai ini menunjukan lemah positif, maksud lemah positif disini adalah tejadi hubungan yang searah antara $X_{2}$ dan $Y_{2}$. Dengan interpretasi bahwa setiap nilai Kualitas Informasi $\left(\mathrm{X}_{2}\right)$ naik, nilai Kepuasan Pemakaian $\left(\mathrm{Y}_{2}\right)$ tidak naik secara signifikan.

4. Jika Kualitas Pelayanan $\left(\mathrm{X}_{3}\right)$ terhadap Kepuasan Pemakaian $\left(\mathrm{Y}_{2}\right)$ adalah sebesar 0,214. Nilai ini menunjukan lemah positif, maksud lemah positif disini adalah tejadi hubungan yang searah antara $X_{3}$ dan $Y_{2}$. Dengan interpretasi bahwa setiap nilai Kualitas Pelayanan $\left(\mathrm{X}_{3}\right)$ naik, nilai Kepuasan Pemakaian $\left(\mathrm{Y}_{2}\right)$ tidak naik secara signifikan.

5. Jika Pemakaian $\left(\mathrm{Y}_{1}\right)$ terhadap Kepuasan Pemakaian $\left(\mathrm{Y}_{2}\right)$ adalah sebesar 0,095. Nilai ini menunjukan lemah positif, maksud lemah positif disini adalah tejadi hubungan yang searah antara $Y_{1}$ dan $Y_{2}$. Dengan interpretasi bahwa setiap nilai Pemakaian $\left(\mathrm{Y}_{1}\right)$ naik, nilai Kepuasan
Pemakaian $\left(\mathrm{Y}_{2}\right)$ tidak naik secara signifikan.

\section{KESIMPULAN}

Berdasarkan hasil penelitian analisis data mengenai kesuksesan penerapan sistem dapodikdasmen menggunakan model delone dan mclean maka dapat disimpulkan sebagai berikut : Tingkat kesuksesan penerapan sistem dapodikdasmen memiliki persentase sebesar 79,43\% , maka penerapan aplikasi sistem dapodikdasmen tersebut dapat dikatakan sukses. Berdasarkan hasil dari pengujian 9 hipotesis yang dirumuskan menghasilkan : 6 hipotesis yang diterima yaitu kualitas sistem terhadap pemakaian, kualitas informasi terhadap pemakaian, kualitas sistem terhadap kepuasan pemakai, kualitas informasi terhadap kepuasan pemakai, kualitas pelayanan terhadap kepuasan pemakai, dan kepuasan pemakai terhadap net benefits, karena thitung lebih besar dari $t_{\text {tabel }}$ dan signifikansi lebih kecil dari 0,05 dan 3 hipotesis yang ditolak yaitu kualitas pelayanan terhadap pemakaian, pemakaian terhadap kepuasan pemakai, dan pemakaian terhadap net benefits, karena thitung lebih kecil dari tabel dan signifikansi lebih besar dari 0,05.

\section{DAFTAR PUSTAKA}

[1] Admaja, Awangga Febian Surya. (2014). Analisis Kesuksesan Sistem Informasi Manajemen Sumber Daya dan Perangkat Pos dan Informatika (SIMS). Buletin Pos dan Telekomunikasi Volume 12, No.2. Hal 105-118

[2] Al Farizi, Musyafa. (2018). Model Kesuksesan Sistem Informasi Delone Dan Mclean Untuk Mengukur Kesuksesan Sistem Informasi Modernisasi Perpajakan E-Billing Menurut Wajib Pajak Badan Kota Semarang, Jurnal MONEX, vol. 7 no. 1. ISSN; 2089-5321. 
[3] Aliyah, Siti, Suyatno, \& Tan, Djuhono. (2015). Pengujian Kesuksesan Sistem Informasi Model Delon Dan Mclean Pada Sector Public. University Research Colloquium.

[4] Antong \& Usman, Halim. (2017). Pengaruh Kualitas Sistem Dan Kualitas Informasi Terhadap Keputusan Pemakai Dan Dampak Individu: Perspektif Model Kesuksesan Delone Dan Mclean (Studi Empirik Sistem Informasi Keuangan Pemerintah Kota Palopo). Jurnal Akutansi Vol. 03 No. 01. ISSN: 2339-1502

[5] Darmawan, Deni. 2013. Metode Penelitian Kuantitatif. Bandung: PT Remaja Rosdakarya.

[6] Delone, W. H. \& Mclean, E. R. 2003. "The Delone And Mclean Model Information System Success: A TenYear Update". Journal Of Management Information Systems. Vol 19 Iss. 4, p. 9-30.

[7] Hari Saputro, Pujo, Dkk. (2015). Model Delone And Mclean Untuk Mengukur Kesuksesan E-Goverment Kota Pekalongan. Scientific Journal Of Informatics Vol. 2, No. 1. ISSN:2407-7658.

[8] Jogiyanto.2007. Model Kesuksesan Sistem Teknologi Informasi. Yogyakarta: Andi.

[9] Jumardi, Rio. Dkk.(2015). Analisis Kesuksesan Implementasi Sistem Informasi Skripsi Pada Program Studi Teknik Informatika Universitas Pembangunan Nasional "Veteran" Yogyakarta. Seminar Nasional Aplikasi Teknologi Informasi (SNATi). ISSN: 1907 - 5022.

[10]Megawati \& Maflukhah, Nur'anini.(2017). Analisis Kesuksesan Penerapan Sistem Informasi Administrasi Kependudukan Menggunakan Model Delone Dan Mclean. Jurnal Ilmiah
Rekayasa Dan Manajemen Sistem Informasi Vol. 3 No. 2. 